\title{
In vitro DPPH and AChE inhibitory activity of hydroethanolic extract from Camellia sinensis (L.) O. Kuntze
}

\author{
Nandhini Baskaran and Anitha Subash • \\ Department of Biochemistry, Biotechnology and Bioinformatics, Avinashilingam Institute for Home Science and Higher Education for Women, \\ Coimbatore-641 043, Tamil Nadu, India
}

\section{Article Info}

Article history

Received 7 September 2021

Revised 27 October 2021

Accepted 29 October 2021

Published Online 30 December 2021

\section{Keywords}

Alzheimer's disease

Camellia sinensis (L.) O. Kuntze

DPPH

Acetylcholinesterase

\begin{abstract}
Alzheimer's disease is a progressive neurodegenerative disorder with neuropsychiatric symptoms and several cognitive functions and is biochemically characterized by a significant decrease in the brain neurotransmitter acetylcholine. Beta-amyloid and Tau protein are the primary causes of Alzheimer's disease (AD), as noted by Alois Alzheimer's in 1906. The focus of the present study, the phytochemical screening, in vitro DPPH and AChE inhibitory activity. Results indicated that hydroethanolic extract of Camellia sinensis (L.) O.Kuntze (HECS) leaves indicated the presence of flavonoids, tannins, glycosides and terpenoides. Phenols, alkaloids, saponins, steroids and phytosteroids. HECS leaves showed DPPH of scavenging activity in dose dependent manner and $\mathrm{IC}_{50}$ value was $30 \mu \mathrm{g} / \mathrm{ml}$ and acetylcholinesterase inhibition effect was also in a concentration dependent manner and the $\mathrm{IC}_{50}$ value obtained was $400 \mu \mathrm{g} / \mathrm{ml}$. Our data suggest that HECS leaves extract possesses significant DPPH activity and AChE activity.
\end{abstract}

\section{Introduction}

Alzheimer's disease (AD) is due to progressive neuronal loss of cognitive function, the common neurodegenerative mental disorder such as thinking, reasoning, memory and behavior which becomes severe as the age progresses and diagnosed in people over 65 years of age. By 2050, the number of AD patients is expected to reach 106 million globally. Around the world, over 7.7 million new cases of dementia are diagnosed each year (Mohideen, 2021). Progression and onset of neurodegenerative disorders like $\mathrm{AD}$ are characterized by hyper phosphorylation as well as aggregation of amyloid plaque deposition, inflammation of neurons, oxidative stress, tau protein and cholinergic hypofunction accompanied by psychological and pathophysiological problem (Yadav et al., 2019; Jyothi and Yellamma, 2016). Inhibition of acetylcholinesterase is considered as a promising strategy for the treatment of some diseases caused by the too low level of AChE, such as glaucoma, myasthenia gravis, gastric motility and Alzheimer's disease (Feng et al., 2015).

Traditional plant with medicinal values are primary healthcare need is followed in underdeveloped countries of about 80 per cent of the world's population. The main reason was that the synthetic drugs which were now taking up the human have many side effects that often lead to series of complications (Rukshana et al., 2017). Plants are the valuable contribution of the inventor to mankind that provides almost the whole thing needed for the survival of individual given that their inception on this earth. Abundant plants are being used as medicines by humans to combat various diseases (Sharma et al.,

Corresponding author: Dr. Anitha Subash

Professor, Department of Biochemistry, Biotechnology and Bioinformatics, Avinashilingam Institute for Home Science and Higher Education for Women, Coimbatore-641 043, Tamil Nadu, India. E-mail: dranithasubash_bc@avinuty.ac.in Tel.: +91-9003704304

Copyright () 2021 Ukaaz Publications. All rights reserved.

Email: ukaaz@yahoo.com; Website: www.ukaazpublications.com
2021; Alam et al., 2019). Currently, a lot of research is being done in medicinal plants, the resource for simple to complex secondary metabolites with impending therapeutic application.These metabolites are effectively known to prevent several chronic diseases including $\mathrm{AD}$, through different mechanisms such as receptor, prevention of oxidative stress, interfering with the cellular signals, modulation of enzymes, etc. (Malar et al., 2017). After water, green tea $(C$. sinensis) is the most consumed beverage in the world. The consumption of teas and herbal infusions has been associated to several health benefits such as, antioxidant and antiageing properties. Oxidative, protection from cardiovascular disease, antiinflammatory, antiobesity, antitumor and antimicrobial activities and neuroprotective activity was anthocyanin composition of an industrial preparation obtained from the cob of purple maize has been studied (Granato $e t$ al., 2016). In this study, we investigated the in vitro DPPH and acetylcholineesterase inhibition activity of hydroethanolic extract of $C$. sinensis leaves.

\section{Materials and Methods}

\subsection{Plant material}

C. sinensis leaves were collected from Aruvankadu in the district of The Niligiri's and taxonomic identification of the plant was confirmed by Botanical Survey of India, Coimbatore (Authentication No: BSI/ SRC/5/23/2015/Tech/270). The samples were cleaned and dried in the shade condition for 10 days at room temperature and were powered and used for further investigation.

\subsection{Preparation of the extract}

To identify the presence of flavonoid in HECS leaves extract, the extraction was undertaken with $10 \mathrm{~g}$ of powdered plant material and $100 \mathrm{ml}$ of petroleum ether (b.p $40^{\circ}-60^{\circ} \mathrm{C}$ ) in a Soxhlet apparatus for 18 hours to remove chlorophyll, non-flavonoid compounds and lipids dewaxing (Palanivel et al., 2008). The treated material was dried and extracted with hydroethanolic solvent $(80 \%$ ethanol - Double distill water with ethanol) using Soxhlet apparatus (Ansari et al., 1976). 


\subsection{Qualitative phytochemical analysis}

The phytochemical qualitative analysis of HECS leaves extract was done by using the standard procedures. Phenols, flavonoids, alkaloids and glycosides were analyzed by the methods given in Akilandaeaswari and Muthu (2020). Terpenoides and steroids were screened by the method described in Arumugam et al. (2011) and tannins by the procedure given in Chetia and Saikia (2020). Saponins was screened by the procedure given in Ejikeme et al. (2014). Phytosterols were analyzed by the method explained in Edeoga $e t$ al. (2011).

\subsection{DPPH radical scavenging activity of HECS leaves extract}

The determination of DPPH scavenging activity of the HECS leaves extract was done by the method of Kulla et al. (2021). The HECS leaves extract $(25 \mu \mathrm{l})$ and $0.48 \mathrm{ml}$ of methanol was added to $0.5 \mathrm{ml}$ of methanolic solution of DPPH. The mixture was allowed to react at room temperature for $30 \mathrm{~min}$. Methanol alone served as blank and DPPH in methanol, without the plant extracts, served as positive control. After $30 \mathrm{~min}$ of incubation, the discolouration of the purple colour was measured at $518 \mathrm{~nm}$. Ascorbic acid was used as a positive control.

The radical scavenging activity was calculated as follows

$$
\text { Scavenging activity }(\%)=\frac{\text { A 518 }(\text { sample })-\text { A 518(control })}{(\text { A } 518 \text { control }) \times 100}
$$

\subsection{In vitro acetylcholinesterase inhibition activity}

The acetylcholinesterase inhibition activity was measured using the method described by Abbod et al. (2020). Briefly, $3 \mathrm{ml}$ of $50 \mathrm{mM}$ Tris-HCl buffer ( $\mathrm{pH} 8.0), 100 \mu \mathrm{l}$ of sample solution at different concentrations $(3 \mathrm{mg} / \mathrm{ml}, 1.5 \mathrm{mg} / \mathrm{ml}, 0.75 \mathrm{mg} / \mathrm{ml})$ and $20 \mu \mathrm{AChE}(6$ $\mathrm{U} / \mathrm{ml}$ ) solutions were mixed and incubated for $15 \mathrm{~min}$ at $30^{\circ} \mathrm{C}$, a $50 \mu \mathrm{l}$ volume of $3 \mathrm{mM} \mathrm{5,50-dithiobis-2-nitrobenzoic} \mathrm{acid} \mathrm{(DTNB)} \mathrm{was}$ added to this mixture. The reaction was then initiated by the addition of $50 \mu \mathrm{l}$ of $15 \mathrm{mM}$ acetylthiocholine iodide (AChI). The hydrolysis of this substrate was measured at precisely $405 \mathrm{~nm}$ wavelength. At this wavelength, the formation of yellow 5-thio-2-nitrobenzoate anion was as a result of the reaction of DTNB with thiocholine, released by the enzymatic hydrolysis of acetylthiocholine iodide. The enzymatic activity was calculated as a percentage of the velocities compared to that of the assay using buffer instead of inhibitor (extract), based on the formula:

$$
\mathrm{EA}=\frac{\mathrm{E}-\mathrm{S}}{\mathrm{E}} \times 100
$$

where EA is enzyme activity (\% inhibition), E is the activity of the enzyme without test sample and $S$ is the activity of the enzyme with test sample.

\subsection{Qualitative evaluation $\mathrm{AChE}$ inhibition using thin layer chromatography (TLC)}

The TLC detection for AChE inhibition was modified from the study of Khodja and Boulebd (2021). A $2.5 \mathrm{~mm}$ silica gel plate F 254 no. 5554 was used as a stationary phase. Two mobile phases, i.e. dichloromethane: ethanol: water 4:4:0.5 (v/v/v) were used. $3 \mu \mathrm{l}$ of plant extract was dissolved in methanol at concentration of $5 \mathrm{mg} / \mathrm{ml}$ and applied to the plate. After the plate had been developed, it was dried at room temperature and then sprayed with $30 \mathrm{mM}$ ATCI followed by $20 \mathrm{mM}$ DTNB. The plate was dried at room temperature for $45 \mathrm{~min}$, and then sprayed with $10.17 \mathrm{U} / \mathrm{ml}$ acetylcholine sterase. After $20 \mathrm{~min}$, the plate was observed under visible light. A positive spot indicating AChE inhibitor was a colourless spot on the yellow background. The result was compared to that from the TLC analysis of the same sample after spraying with an is Aldehyde and Dragendorff's re agents (Rhee et al., 2001).

\subsection{Statistical analysis}

The parameters analyzed of the study were subjected to statistical treatment using SigmaStat Statistical package. All measurements were expressed as mean \pm standard deviation. Statistical significance was determined by one-way ANOVA. Values of $p<0.05$ were considered significant.

\section{Results}

\subsection{Qualitative phytochemical analysis}

The qualitative phytochemical screenings of HECS leaves extract is presented in Table 1. The extracts showed the presence and absence by color change of phytochemicals like flavonoids, tannins, glycosides and terpenoides. Phenols, alkaloids, saponins, steroids and phytosteroids were also present in minor quantities.

Table 1: Phytochemical screening for HECS leaves extract

\begin{tabular}{|c|l|c|}
\hline S.No & Photochemical & HECS leaves extract \\
\hline 1. & Alkaloids & + \\
2. & Phenols & + \\
3. & Flavonoids & +++ \\
4. & Tannin & +++ \\
5. & Glycosides & +++ \\
6. & Saponin & + \\
7. & Terpenoides & +++ \\
8. & Steroids & + \\
9. & Phytosteroids & ++ \\
\hline
\end{tabular}

+++ > ++ >+ : Represents intensity of color formation (Presence of specific compounds): Represents no color formation (Absence of specific compounds).

3.2 DPPH radical scavenging activity of HECS leaves extract

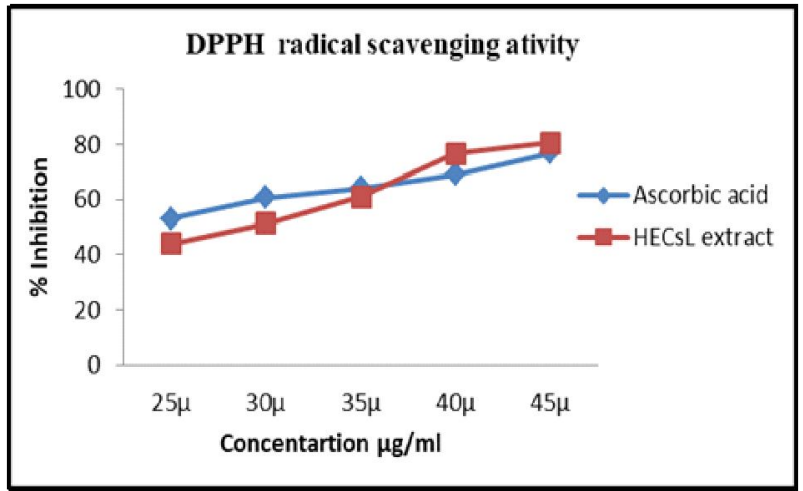

Figure 1: DPPH scavenging activity of HECS leaves extract. 
The percentage inhibition scavenging activity of HECS leaves extract for DPPH is shown in Figure 1. The per cent inhibition of scavenging activity of the HECS leaves extract was increasing in dose dependent manner which was comparable to that of standard (ascorbic acid) at the same concentration. $\mathrm{IC}_{50}$ value of the HECS leaves extract was determined to be the $30 \mu \mathrm{g} / \mathrm{ml}$, the percentage inhibition was $86.37 \%$.

\subsection{In vitro acetylcholinesterase inhibition activity}

The per cent of inhibition activity of AChE at different concentrations $(12.5,25,50,100,200$, and $400 \mu \mathrm{g} / \mathrm{ml})$ of HECS leaf extract is presented in Figure 2.

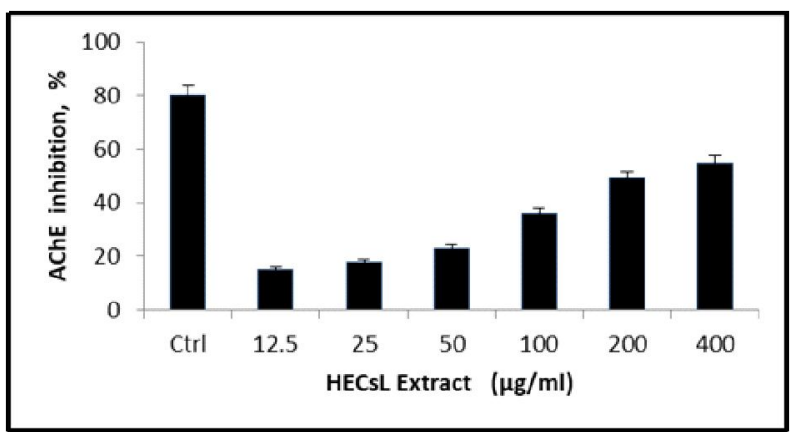

Figure 2: Acetylcholinesterase (AChE) inhibitory activity of HECS leaves extract.

The AChE inhibitory effects was found to be in a concentration dependent manner as it was found to increase as concentration increased, and the $\mathrm{IC}_{50}$ value was found to be $400 \mu \mathrm{g} / \mathrm{ml}$.

3.4 Qualitative evaluation AChE inhibition using thin layer chromatography (TLC)

TLC qualitative of HECS leaves extract showed the presence of single spot with Rf value - 0.63. The spot appeared as white spot against a yellow background as shown in Figure 3 .

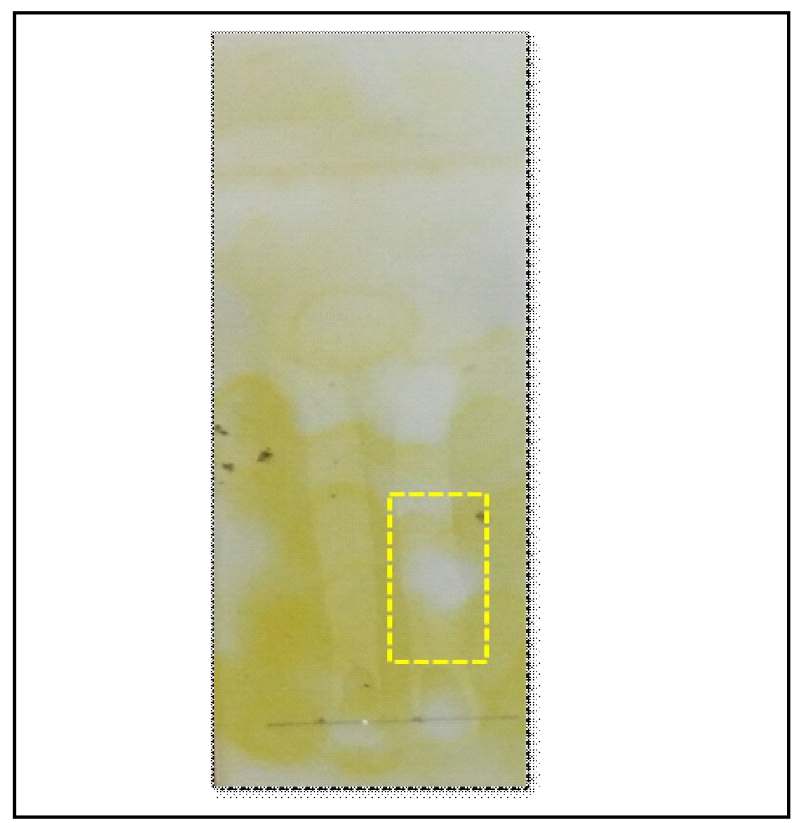

Figure 3: Qualitative acetyl cholinesterase inhibition assay of HECS leaves extract by TLC.

\section{Discussion}

Sivakumar and Jeganathan (2018) reported the presence of alkaloids, anthraquinones, cardiac glycosides, flavonoids, reducing sugars, saponins, steroids, phenol, carbohydrate, tannins and anthraquinone in the Orthosiphon stamineus tea leaves extracts. Phytochemical screening by Surjanto et al. (2019), presence of alkaloids, tannins, saponin, flavonoids and triterpenoids in the gaharu leaf tea (Aquilaria malaccensis Lamk) as raw material of tea from middle Tapanuli Regency. Xu et al.,(2019) reported the presence of phytochemicals in the green tea extract. Yang et al. (2007) reported water extract from $C$. sinensis tea flower and their fractions showed lower antioxidant activity for their inhibitory effect on hydroxyl radicals and DPPH radicals. Yang et al. (2009). The present compounds soluble in ethyl acetate-soluble fraction had comparatively contributed to strong antioxidant activity and DPPH radical scavenging activity of the $C$. sinensis flowers. Methanol and acetone extracts of Ficus bengalensis (aerial root) and Ficus racemosa (stem bark) were evaluated for their antioxidant activity and radical scavenging potential in comparison with $C$. sinensis (green tea). All the above plant extracts are exhibited, had antioxidant activity against the linoleic acid emulsion system (Manian et al., 2018). According to the obtained results, such as antioxidant activity and radical scavenging activity shown significantly similar to previous report. Feitosa et al. (2011) results were exhibited acetylcholinestrase inhibitors, are successfully used to treat the symptoms of Alzheimer's disease. Malar et al. (2017) showed that methanolic extract of Grewia tiliaefolia leaf as a dual cholinesterase inhibitor. The study of Ghareeb et al. (2014) reported that plant extract from Chlorella vulgaris, most potent inhibitor for AChE activity, it had the lowest $\mathrm{IC}_{50}(40 \pm 2.3 \mu \mathrm{g} / \mathrm{ml})$. In a previous study, Mukherjee et al. (2007) reported a hydroalcohol extract of Nelumbo nucifera rhizome showed weak AChE inhibitory activity with an $\mathrm{IC}_{50}$ value of $185.55 \pm 21.24 \mathrm{mg} / \mathrm{ml}$. Mathew and Subramanian (2014) also studied the methanolic extracts of Emblica officinalis, Nardostachys jatamansi, Nelumbo nucifera, Punica granatum and Raulfia Serpentina showed $\mathrm{IC}_{50}$ values, $100 \mathrm{mg} / \mathrm{ml}$ for acetylcholinesterase inhibitory activity.

\section{Conclusion}

The reported results of the present investigation of phytochemicals in HECS leaves extract that revealed potential of DPPH and AChE inhibitory action. These findings imply that the antiacetylcholinesterase activity of HECS leaves extract could be investigated for its therapeutic relevance in free radical-mediated diseases such as Alzheimer's disease Parkinson's disease, and cancer.

\section{Acknowledgments}

The author thankful to Avinashilingam Institute for Home Science and Higher Education for Women, University, Coimbatore, for providing adequate help required to carry out the present work.

\section{Conflict of interest}

The authors declare no conflicts of interest relevant to this article.

\section{References}

Abbod, M.; Safaie, N.; Gholivand, K.; Mehrabadi, M. and Bonsaii, M. (2020). Mode of action of 3-butylidene phthalide as a competent natural pesticide. Pesticide Biochem. and Physiology, 1-9. https://doi.org/10.1016/ j.pestbp.2020.02.003. 
Akilandaeaswari, B. and Muthu, K. (2020). Green method for synthesis and characterization of gold nanoparticles using Lawsonia inermis seed extract and their photocatalytic activity. Mater. Lett., 277: 128344.https://doi.org/10.1016/j.matlet.2020.128344.

Alam, A.; Kanchan and Iwuala, E. (2019). Contemporary medicinal uses of ethnomedicinally important plant: Arjuna (Terminalia arjuna (Roxb.) Wight and Arn.). Ann. Phytomed., 8(1):63-69.

Ansari, W.H.; Rahman, W.; Barraclough, D.; Maynard, R. and Scheinman, F.S. A. (1976). New acylated apigenin 4 '-O- $\beta$-D-glucoside from the leaves of Lycopodium clavatum L. Chem. Soc., 2:14-58. https://doi.org/ 10.1055/s-0028-1097269.

Arumugam, T.; Ayyanar, M.; Pillai, Y. J. K. and Sekar, T. (2011). Phytochemical screening and antibacterial activity of leaf and callus extracts of Centella asiatica. Bangladesh J. Pharmacol., 6:55-60. https://doi.org/ 10.3329/bjp.v6i1.8555.

Chetia, J. and Saikia, L. R. (2020). Phytochemical analysis of Leucas aspera (Willd.) Link. from Dibrugarh. J. Scie. Res., 64(2):96-103. https:/ /doi.org/10.37398/JSR.2020.640212.

Edeoga, H.O.; Okwe, D.E. and Mbabie, B.O. (2011). Phytochemical constituents of some Nigerian medicinal plant. Agric. J. Biotechnol., 4(7):685688. DOI: 10.5897/AJB2005.000-3127.

Ejikeme, C. M.; Ezeonu, C. S. and Eboatu, A. N. (2014). Determination of physical and phytochemical constituents of some tropical timbers indigenous to Niger Delta area of Nigeria. Euro. Scientific J., 10(18):247-270. DOI: https://doi.org/10.19044/esj.2014.v10n18p\%25p.

Feitosa, C.; De Freitas, R. M.; Luz, N.; zBezerra, M. and Trevisan, M. (2011). Acetlcholiesterase inhibition by somes promising Brazilian medicinal plants. Braz.. J. Bio., 71:783-789. https://doi.org/10.1590/ S1519-69842011000400025

Feng, X.; Wang, X.; Liu, Y. and Di, X.L. (2015). Linarin inhibits the acetylcholinesterase activity In vitro and ex vivo. Iran. J. Pharm. Res., 14(3):949-954. PMCID: PMC4518125

Ghareeb, D.A.; ElAhwany, A.M.D.; El-mallawany, S. M. and Saif, A.A.(2014). In vitro screening for anti-acetylcholiesterase, antioxidant, antiglucosidase, anti-inflammatory and antibacterial effect of three traditional medicinal plants. Biotech. and Biotechn. Equ., 28(6): 1155-1164. https://doi.org/10.1080/13102818.2014.969877.

Granato, D.; Prado-Silva, L.; Alvarenga, V.O.; Zielinski, A.A.F.; Bataglion, G. A.; Morais, D. R.; Eberlin, M. N. and SantAna, A. S. (2016).Characterization of binary and ternary mixtures of green, white and black tea extracts by electrospray ionization mass spectrometry and modeling of their in vitro antibacterial activity. LWT - Food Sci. Tech.,65: 414420. http://dx.doi.org/10.1016/j.lwt.2015.08.037

Jyothi, P. and Yellamma, K.. (2016). Molecular docking studies on the therapeutic targets of Alzheimer's disease (AchE and BchE) using natural bioactive alkaloids. inter. J. Phar. Pharm. Sci., 8(12):108-112. DOI https://doi.org/10.22159/ijpps.2016v8i12.14833.

Khodja, A. and Boulebd, H. (2021). Synthesis, biological evaluation, theoretical investigations, docking study and ADME parameters of some 1,4 bisphenylhydrazone derivatives as potent antioxidant agents and acetylcholinesterase inhibitors. Mol. Diversity., 25:279290. https://doi.org/10.1007/s11030-020-10064-8.

Kulla, S.; Hymavathi, T.V.; Anila Kumari, B.; Geetha Reddy R. and Durga Rani Ch.V. (2021). Impact of germination on the nutritional, antioxidant and antinutrient characteristics of selected minor millet flours. Ann. Phytomed., 10(1):178-184. http://dx.doi.org/10.21276/ ap.2021.10.1.18.
Malar, D.B.; Shafreen, R.B.; Pandian, S.K. and Devi, K.P. (2017). Cholinesterase inhibitory, anti-amyloidogenic and neuroprotective effect of the medicinal plant Grewia tiliaefolia: An in vitro and in silico study. Pharma. Bio., 55(1):381-393.https://doi.org/10.1080/13880209 2016. 1241811

Manian, R.; Anusuya , N.; Siddhuraju, P. and Manian S. (2008). The antioxidant activity and free radical scavenging potential of two different solvent extracts of Camellia sinensis (L.) O. Kuntz, Ficus bengalensis L. and Ficus racemosa L. Food Chemistry, 107(3):1000-1007. https://doi.org/10.1016/j.foodchem.2007.09 .008

Mathew, M. and Subramanian, S. (2014). In vitro screening for anticholinesterase and antioxidant activity of methanolic extracts of Ayurvedic medicinal plants used for cognitive disorders. PLoS ONE, 9(1):e86804. doi:10.1371/journal.pone.0086804

Mohideen, A.P.(2021). In silico identification of novel immunostimulating phytochemicals with acetylcholinesterase inhibition activity from Piper betle L. and Vitex negundo L. for the treatment of Alzheimer's disease (AD). Ann. Phytomed. 10(1):86-95. http://dx.doi.org/ 10.21276/ap.2021.10.1.9

Mukherjee, P.K.; Kumar, V. and Houghton, P.J. (2007). Screening of Indian medicinal plants for acetylcholinesterase inhibitory activity. Phytother. Res., 21:1142-1145. doi: 10.1002/ptr.2224.

Palanivel, M. G.; Balasubramanian, R.; Raju, S. K.; John, W.E.; Ekambarm, P.K.; Mani, R. K.; Kanchu, K.; Mohanraj, P.K. and Balasundram, J. (2008). Hepatoprotective and antioxidant effect of Pisonia aculeate L. against CCl4 induced hepatic damage rats. Sci Pharm.,76:203-215 http://dx.doi.org/10.3797/scipharm.0803-16

Rhee, I.K.; Van der Meent, M.; Ingkaninan, K. and Verpoorte, R. (2001). Screening for acetylcholinesterase inhibitors from amaryllidaceae using silica gel thin-layer chromatography in combination with bioactivity staining. J. Chroma., 915:217-223. https://doi.org/10.1016/S00219673(01)00624-0.

Rukshana, M.S.; Doss, A. and Kumari Pushpa Rani, T.P.(2017). Phytochemical screening and GC-MS analysis of leaf extract of Pergularia daemia (Forssk) Chiov. Asian J. Pla. Sci. and Res., 7(1):9-15. www.pelagiares earchlibrary.com.

Sharma, B.; Sharma, S. C. and Alam, A. (2021). Phytochemical screening and GC-MS analysis of Tamarindus indica L. (Angiosperms: Fabaceae). Ann. Phytomed., 10(1):215-221. http://dx.doi.org/10.21276/ ap.2021.10.1.23

Sivakumar, C. and Jeganathan, K. (2018). Phytochemical profiling of cat whisker's (Orthosiphon stamineus) tea leaves extract. J. Pharmacog. and Phytochem., 7(6):1396-1402. http://dx.doi.org/10.22271/ phyto.

Surjanto.; Batubara R.; Hanum, T. I. and Pulungan, W. (2019). Phytochemical and antioxidant activity of gaharu leaf tea (Aquilaria malaccensis Lamk) as raw material of tea from middle Tapanuli Regency, North Sumatera Province IOP. Conf. Series: Ear. Env. Sci., 260:012101. https://doi.org/10.1088/1755-1315/260/1/012101.

Xu, X.; Meng, J.; Mao, Q.; Shang, A.; Li, B.; Zhao, C.; Tang, G.; Cao, S.; Wei, X.; Gan, R.; Corke, H. and Li, H. (2019). Effects of tannase and ultrasound treatment on the bioactive compounds and antioxidant activity of green tea extract. Antioxi., 8(362):1-14. https://doi.org/10.3390/ antiox 8090362 .

Yadav, E.; Singh, D.; Debnath, B.; Rathee, P.; Yadav, P. and Verma, A. (2019). Molecular docking and cognitive impairment attenuating effect of phenolic compound rich fraction of Trianthema portulacastrum in scopolamine induced Alzheimer's disease like condition. Neuro- 
chemical Res., 44:1665-1677. https://doi.org/10.1007/s11064-01902792-7.

Yang Z.; Xu, Y.; Jie, G.; He, P. and Tu, Y. (2007). Study on the antioxidant activity of tea flowers (Camellia sinensis). Asia Pacific Journal of Clinical Nutrition Supplement, 1(16):148-152.
Yang, Z.; Tu, Y.; Baldermann, S.; Dong F.; Xu, Y. and Watanabe, N. (2009). Isolation and identification of compounds from the ethanolic extract of flowers of the tea (Camellia sinensis) plant and their contribution to the antioxidant capacity. LWT - Food Science and Technology, 42(8):1439-1443. https://doi.org/10.1016/j.1wt.2009.03.017.

Nandhini Baskaran and Anitha Subash (2021). In vitro DPPH and AChE inhibitory activity of hydroethanolic extract from Camellia sinensis. Ann. Phytomed., 10(2):208-212. http://dx.doi.org/10.21276/ap.2021.10.2.29 